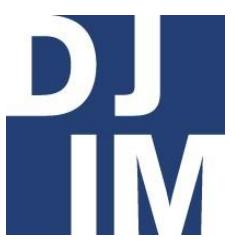

Volume 14

Spring

2018

djim.management.dal.ca |

\title{
The Eye of the Storm: Extreme Weather Events and Sustainable Urban Forest Management
}

Kendra Alair Marshman

School of Resource and Environmental Studies, Dalhousie University

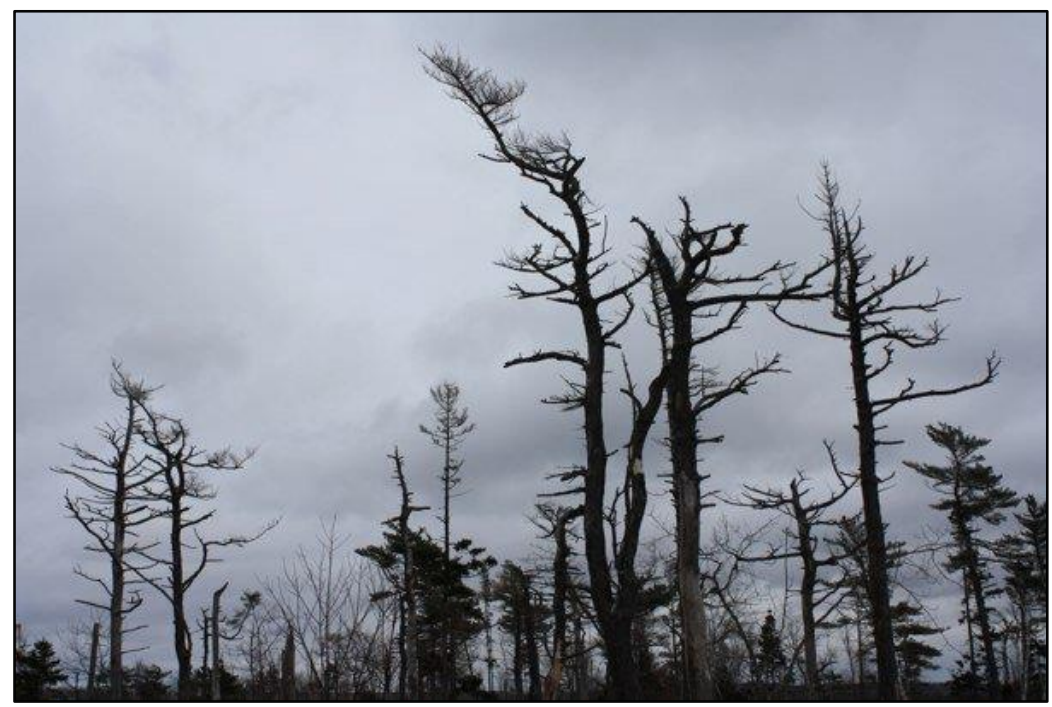

Post Hurricane Juan Point Pleasant Park - Kendra Marshman

\section{Abstract}

More people live in cities today than ever before. One indicator of a sustainable urban environment is a full canopy cover. Urban residents value trees for the benefits of improved air quality, provision of shade, and aesthetic purposes, among others. Although urban trees are greatly valued, they are up against environmental challenges. Global climate change threatens urban forests because of the accompanying increase in frequency and intensity of extreme weather events. Such events include hurricanes, intense precipitation, windstorms, 
and ice storms. In Halifax (2003) Hurricane Juan negatively affected the urban forest canopy and some areas have not fully recovered. Similarly, in Vancouver's Stanley Park (2006 \& 2007) an extreme windstorm hit the urban canopy. How can urban forest planners adapt the urban forest to become more resilient in the face of such events?

\section{Introduction}

Global climate change is a threat to urban forests worldwide because of the accompanying increase in frequency and intensity of extreme weather events. Increasingly, cities are developing urban forest master plans (UFMPs) to ensure the protection and sustainable management of trees in the city. As the trend of living in cities continues, UFMPs will become increasingly important in ensuring sustainable management of urban trees.

Urban forest planners have made strides toward planning and managing for forest resilience to extreme weather events. This paper uses the Halifax UFMP's definition of the urban forest, which includes all trees in the city (HRM Urban Forest Planning Team, 2013). One tool used by urban forest planners and municipalities to manage the urban forest are UFMPs. UFMPs focus on maintaining and improving benefits provided by urban trees. A UFMP is a set of established policies that guide a municipality towards a sustainable urban forest management (SUFM) (HRM Urban Forest Planning Team, 2013). UFMPs have been used effectively to plan for and monitor the effects of climate change on urban trees.

Trees in the city are valued for their ecological, social, and health benefits, among others. Using a sidewalk inception survey, Ordóñez, Duinker, Sinclair, Beckley,
\& Diduck determined urban forest values from citizens of Fredericton, Halifax, and Winnipeg (2016). Highly valued benefits of the urban forest include improved air quality, shade, aesthetics, and naturalness, among others (Ordóñez et al., 2016). Other urban forest benefits include increased property value, community safety, and reduction of heating and cooling costs (van Wassenaer, Schaeffer, \& Kenney, 2000). Urban forest planners consider their citizenry's social and environmental values when determining when, where, and what to plant (Konijnendijk, 2008).

The Halifax UFMP emerged after categorytwo Hurricane Juan devastated canopy cover in 2003. The Halifax UFMP plans for forest resilience in the face of increasing extreme weather events (HRM Urban Forest Planning Team, 2013). Similarly, extreme windstorms in Vancouver led to an urban forest restoration plan (Vancouver Park Board, 2007). Using these two historical examples as well as contemporary events in a media analysis, the immediate and long-term effects of extreme weather events on urban forests are examined herein. From this analysis, this paper explores potential adaptations for urban forest management to ensure urban forests become more resilient in the face of such events. 


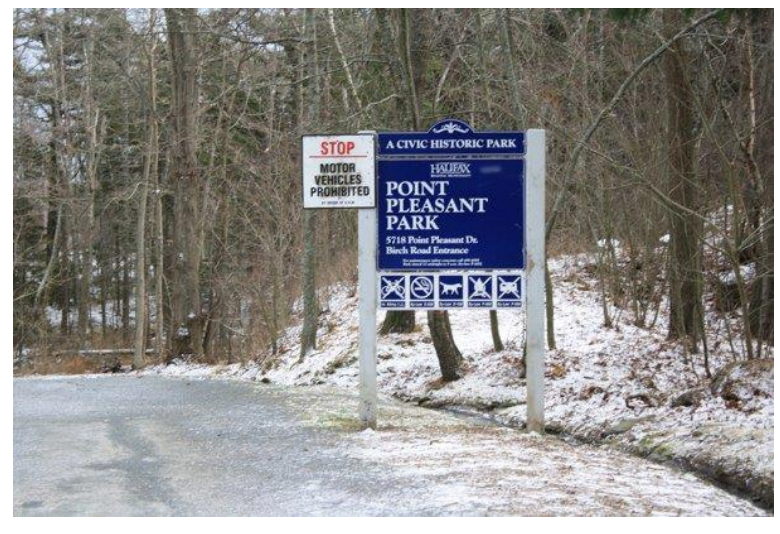

Figure 1. Entrance to Point Pleasant Park, Halifax Nova Scotia, Kendra Marshman

\section{The Urban Forest of Point Pleasant Park}

Point Pleasant Park (see Figure 1), in south end Halifax Nova Scotia, is one of Canada's oldest parks (HRM Urban Forest Planning Team, 2013). It was originally used as the site for military defense (Steenberg \& Duinker, 2010). The area was repeatedly clear-cut because trees and vegetation limited visibility of oncoming attacks from the Americans and French (Steenberg \& Duinker, 2010). Currently, Point Pleasant Park is under a 999-year lease from the Crown as a culturally significant public park within walking distance to downtown Halifax (NIPpaysage \& Ekistics Planning and Design, 2008). Point Pleasant Park offers Halifax citizens the opportunity to enjoy the many benefits provided by the urban forest.

Point Pleasant Park is within the Nova Scotia Acadian Forest Region. The forest conditions of Point Pleasant Park do not greatly vary from the majority of the Maritimes provinces, where Acadian forest species dominate (Steenberg \& Duinker, The Eye of the Storm
2010). Dominant Acadian Forest Region species are red spruce, white pine, yellow birch, and sugar maple, among others (Steenberg \& Duinker, 2010). Prior to Hurricane Juan, the dominant coniferous species in the park were red spruce and white pine and the dominant nonconiferous species were red maple, sugar maple, yellow birch, white birch, and red oak (Steenberg \& Duinker, 2010). Red spruce has been identified as a dominant regenerating species in the park postHurricane Juan (Steenberg \& Duinker, 2010).

Roughly $80 \%$ of total canopy cover of Point Pleasant Park was lost on 29-September2003 to category 2 Hurricane Juan (Steenberg \& Duinker, 2010). Sustained winds during Hurricane Juan reached 185 $\mathrm{km} /$ hour (NIPpaysage \& Ekistics Planning and Design, 2008). Damage from the storm extended well beyond Point Pleasant Park, spreading over a $70 \mathrm{~km}$ wide corridor throughout central Nova Scotia (McGrath \& Ellingson, 2009). The impacts of Hurricane Juan on urban trees are noticeable to this day in Point Pleasant Park.

After Hurricane Juan, the public urged local officials to take action in replacing some of the lost trees (Steenberg \& Duinker, 2010). A healthy mixed-Acadian forest might not regenerate without human intervention, making management plans crucial (NIPpaysage \& Ekistics Planning and Design, 2008). Halifax Regional Municipality (HRM) invited the public to a consultation 
about park restoration (NIPpaysage \& Ekistics Planning and Design, 2008). Taking the public's values into consideration, HRM and Dalhousie University have conducted studies to determine the park's ability to naturally regenerate and to create adaptive management plans to increase forest resilience to extreme weather events.

\section{The Urban Forest of Stanley Park}

Stanley Park (see Figure 2) is in downtown Vancouver, British Columbia. Established in 1888, it is the oldest park in Vancouver offering educational and recreational benefits to roughly eight million visitors a year (Vancouver Park Board, 2007). Local visitors and tourists enjoy the feeling of being immersed in nature without having to leave the city (Kheraj, 2013).

Vancouver's Stanley Park is situated in the Coastal Western Hemlock Biogeoclimatic Zone (Kheraj, 2013). The tree species that dominate this zone include western red cedar, Douglas fir, and western hemlock (Kheraj, 2013). The dominant tree species in Stanley Park are consistent with these. Vancouver Park Board forest restoration policies plan for a forest aesthetic that the public expect from the park, which is one of an untouched environmental (Kheraj, 2007). Historically, aesthetics have been an important consideration in forest planning for Stanley Park as tourists enjoy the view of cedars and firs against the backdrop of the Pacific ocean and mountains beyond (Kheraj, 2013).
Stanley Park has witnessed a pattern of extreme weather events including extratropical cycle Hurricane Freda in 1962 (Kheraj, 2007). In 2006 \& 2007 a series of three major windstorms occurred in the span of less than four weeks (Vancouver Park Board, 2007). During this time, over 10,000 trees were downed, which was roughly $5-10 \%$ of all trees in Stanley Park at the time (Vancouver Park Board, 2007). 30 ha of the parkland suffered severe damage and another 50ha suffered moderate damage (Vancouver Park Board, 2007). Extreme weather events such as these negatively affect the public's ability to enjoy urban forest benefits.

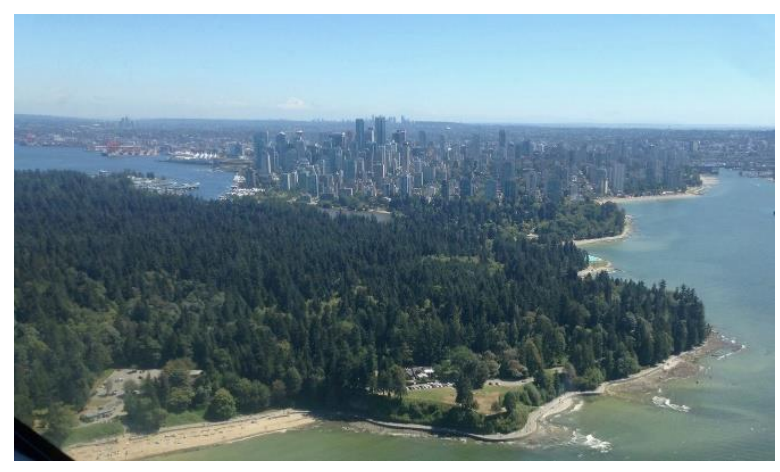

Figure 2. Arial Photo of Stanley Park-Vancouver Ellen Chappell

\section{Context: Climate Change and Urban Forests}

Global temperatures are increasing at a rate faster than in pre-industrial times (IPCC, 2014). Urban areas have and will continue to experience heat stress, storms, extreme precipitation, sea level rise, and storm surges (IPCC, 2014). This is significant as the worldwide trend towards living in cities continues (van Wassenaer et al., 2000). As temperatures rise, frequency and intensity 
of extreme weather events will also increase (Ordóñez \& Duinker, 2014). Halifax is experiencing a one-hundred-year trend toward increased hurricane frequency (Burley, Robinson, \& Lundholm, 2007). Of the many challenges that urban forests face, climate change, extreme weather events, impoverished, disturbed soil, and harsh growing conditions are among them (Steenberg et al., 2013). This paper focuses specifically on how extreme wind events have affected two forested urban parks on opposite coasts of Canada.

Roughly $80 \%$ of Canadians now live in cities (Statistics Canada, 2017). As society becomes increasingly urban, more people turn to the urban forest as their main exposure to nature (Steenberg, Duinker, \& Charles, 2013). Well-treed urban parks offer urban residents ample opportunity to enjoy urban forest benefits. The benefits of trees are enhanced and protected through sustainable urban forest management in the form of UFMPs. The Halifax UFMP and the Vancouver forest restoration plan were developed after extreme weather events in part to ensure preparedness in the likely reoccurrence of such events. As extreme weather events increase as a result of climate change, planning for urban forest resilience becomes more important.

\section{Urban Forest Management at Point Pleasant Park}

Point Pleasant Park's location made it vulnerable to extreme damage. Point Pleasant Park is isolated from potential seed sources as it is surrounded by The Eye of the Storm saltwater and residential land uses (Burley et al., 2007). Park trails contribute to further park fragmentation (Steenberg \& Duinker, 2010). A fragmented forest like post-Juan Point Pleasant Park recovers from impact slower than those closer to old growth forests because of human influence and vegetation removal (Burley et al., 2007). Therefore, sustainable urban forest management and monitoring of forest regeneration is necessary to ensure urban forest benefits can be enjoyed by current and future generations.

A comprehensive management plan was created for Point Pleasant Park in 2008 in collaboration between NIPpaysage and Ekistics Planning and Design. This plan called for adaptive management of the park (NIPpaysage \& Ekistics Planning and Design, 2008). Adaptive management is a learning approach to natural resource management where strategies for management are experiments (Armitage, Berkes \& Doubleday, 2007). The goal of adaptive management is an integrative understanding of the system at hand (Armitage, Berkes \& Doubleday, 2007). The theory of resilience is increasingly overlapping with adaptive management, as management goals prioritize increasing resilience of a system. Resilience can be defined as the capacity of a system to absorb disturbance while undergoing change while maintaining its function and structure (Berkes \& Ross, 2013). NIPpaysage \& Ekistics Planning and Design (2008) suggested a central management system with more staff, and most 
importantly the goal of improving forest resilience for the enjoyment of future generations.

The suggestions of the 2008 comprehensive plan were informed by public involvement and aesthetics, among others (NIPpaysage \& Ekistics Planning and Design, 2008). Ideally, Point Pleasant Park will regenerate into a natural Acadian dominated canopy because citizens of Halifax want to see those species (Steenberg \& Duinker, 2010). Point Pleasant Park's species focus is consistent with the Government of Nova Scotia's: sugar maple, yellow birch, red oak, eastern hemlock, white pine, and red spruce (NIPpaysage $\&$ Ekistics Planning and Design, 2008; Steenberg \& Duinker, 2010). To maintain the natural forest aesthetic, natural regeneration is encouraged followed by human assisted reforestation (NIPpaysage \& Ekistics Planning and Design, 2008).

Similar to the comprehensive plan, the Halifax UFMP takes an adaptive management approach to urban forestry. Adaptive management considers changing forest structure and citizen values (UFMP Planning Team, 2013). It includes creating and testing hypotheses, measuring outcomes during and after implementation, and comparing predictions and management (UFMP Planning Team, 2013, p. 105). Multiple stakeholders establish an experimentation process and the response of the system to actions are closely monitored (Duinker \& Trevisan, 2003, p. 860). Adaptive management is used to manage Point Pleasant Park's trees because according to the HRM Urban Forest Planning Team (2016) the park is entering a period of rapid change. Sustained monitoring and assessing of the urban forest is critical for adaptive management to succeed (Duinker \& Trevisan, 2003).

Natural regeneration post-Hurricane Juan was carefully monitored in study by Steenberg \& Duinker (2010). Prior to Hurricane Juan, Point Pleasant Park was dominated by mature, red spruce trees (NIPpaysage \& Ekistics Planning and Design, 2008). Steenberg \& Duinker (2010) found that red spruce made up $60 \%$ of regenerated species. As a long-lived, shade tolerant, Acadian species, red spruce is favourable species for natural regeneration (Steenberg \& Duinker, 2010). Careful, longterm monitoring in the form of academic studies is critical to fulfilling adaptive management goals of the Halifax UFMP and the Point Pleasant Park comprehensive plan.

\section{Urban Forest Management at Stanley Park}

Immediately after the three Vancouver windstorms in 2006 \& 2007, a restoration plan was developed for Stanley Park (Vancouver Park Board, 2007). The primary goal of the plan was to "establish and maintain conditions in the blowdown areas that will foster a resilient coastal forest with a diversity of native tree and other species and habitats, using methods and equipment that protect the environment, park visitors, workers, and volunteers" 
(Vancouver Park Board, 2007, p. 4). Like HRM, the Vancouver Park Board plans for increased forest resilience in the face of increased frequency and intensity of extreme weather events. Vancouver Park Board planners strive for resilient urban forest systems that maintain function while conditions continually change (Berkes \& Ross, 2013). Their restoration plan put forward recommendations to be taken by the city.

The plan's primary goal of forest resilience was to be implemented in a variety of ways. First, action was taken in 2006 and 2007 immediately after the storm to clear fallen trees from roads, and later from public areas such as trails (Vancouver Park Board, 2007). Forest structure was to be retained, including some course woody debris. The amount of coarse woody debris on the forest floor increased from around 80 t/ha to 400-600 t/ha per hectare after the three storms (Vancouver Park Board, 2007). Poststorm, levels of course woody debris were to be retained back to $80-120$ t/ha to ensure proper forest aging (Vancouver Park Board, 2007). Few studies were available to measure the successes of park workers and volunteers in retaining proper amounts of course woody debris.

The Vancouver Park board recommended human assisted regeneration for Stanley Park. A diversity of tree species was to be planted post-storm including Douglas-fir, western redcedar, Sitka spruce, Grand fir, Bigleaf maple, Red alder, and a variety of shrubs (Vancouver Park Board, 2007).
Hemlocks were not planted because they regenerate naturally and are less wind and storm resilient (Vancouver Park Board, 2007). The results of these planting goals need to be studied to determine if implementation was successful.

\section{Media Coverage Analysis: How Do Headlines Define a Storm?}

Hurricane Juan is remembered for its intensity and destruction. News coverage at the time of the event and afterwards immortalized the event as destructive in citizen's collective consciousness. Immediately after the event, Art Sampson, former supervisor of major parks for Halifax, was interviewed by Macleans (Demont, 2003). Sampson remarked upon his life's work that Point Pleasant Park "looks like a giant has used it as a bowling alley" (Demont, 2003, p. 1). In the same interview, Halifax urban forester John Simmons commented that hurricanes will find the weaknesses of every tree, whether it is its roots, canopy, trunk, or branches. Simmons' comment can be interpreted as a warning to plan for urban forest resilience to extreme weather events.

News headlines informed the public of Juan's destructive nature. Headlines include Destructive and Deadly Juan (2016) and $A$ Decade Later, Hurricane Juan's Destructive Legacy Lingers in Halifax (Deadly and Destructive Juan, 2016; Patten, 2013). Halifax supervisor of urban forestry Kevin Osmond stated that damage to the canopy can be seen over 15 years after a major windstorm (Berman, 2015). When 
windthrow events occur they are documented as exceptional phenomenon when in fact they are recurrent drivers of ecosystem processes (Mitchell, 2013). The reader is informed of the magnitude of the storm, but these headlines do little to warn that such events are likely to become more frequent and intense. Rather, these headlines frame events like Hurricane Juan as rare and unexpected, which can justify unpreparedness.

Similar to Hurricane Juan, news headlines immediately and long after the 2006 and 2007 Vancouver windstorms described a destructive force beyond anyone's control. Headlines include Storm Ravaged Stanley Park (Sin, 2006) and Vancouver's Stanley Park Shows Signs of Recovery a Year After Storm Wrecked Havoc (Vancouver's Stanley Park Shows Signs of Recovery a Year After Storm Wrecked Havoc, 2017). On the other hand, some Vancouver media coverage emphasized human actions taken after the storms, such as volunteers planting seedlings (Talmazan, 2016) and donations from individuals through an adopt a tree program (Sin, 2006). Vancouver residents value recreational time and other benefits provided by trees in Stanley Park and acted to protect those benefits for future generations.

After an extreme weather event, headlines are likely to first emphasize issues of human health, safety, and infrastructure damage before effects on urban trees. When trees are mentioned, it is often the consequences of trees falling on something or someone that is reported, not the loss of urban forest benefits. One example of this comes from recent Storm Ophelia in Ireland. Storm Ophelia Ripped the Roof off Ireland Today (2017) is a photo journal of hurricane force winds that killed three people and ripped trees out of the ground by their roots. The public is warned of the danger of large branches and trees felled by wind (Storm Ophelia Ripped the Roof off Ireland Today, 2017). The significance of the loss of urban forest benefits are often not realized until months or years after a storm. When media coverage of storms neglect to report the lost value of mature trees, an opportunity is missed to educate the public on urban forest benefits.

The media can demonize urban trees for their potential to cause damage during extreme weather events. In the wake of Storm Ophelia, the city and the public were involved in a debate about the place of trees in the public realm (English, 2017). English (2017) reported on a call for a full review of Cork City's tree policy. Cork City argued that a damage assessment was urgently needed after they received one hundred an fourteen calls about felled trees (English, 2017). One city councilor wants to reexamine what is being planted, emphasizing the danger of falling trees (English, 2017). Their concerns do not consider the benefits urban trees provide, such as stormwater retention. Trees counteract some adverse effects of water runoff on impervious surfaces (Steenberg et al., 2013). Such news stories can 
discourage homeowners from planting trees and promoting urban forest benefits.

In some cases, extreme weather events serve as catalysts for municipal action. Such action can be positive, as was the case in the United States. Hurricane Katrina was a catalyst for the U.S Forest Service's Urban and Community Forestry Program, a 10year nation-wide program between state forestry agencies (Matheson, 2017). This program was active for Hurricanes Harvey, Irma, Maria, and Nate, where first responders were involved as members of Urban Forest Strike Teams (UFST). Born out of frustration over damaged but viable trees being cut down after storms, UFSTs are highly trained groups who walk the city streets after storms, assess damage, and enter GIS data to support mitigation and recovery strategies (Matheson, 2017). An extreme weather event led to increased management strategies for protecting urban trees in the United States.

A recent severe weather event distressed canopy cover in the Maritimes. Posttropical storm Arthur fell on New Brunswick on July 5, 2014, damaging infrastructure and causing power outages (New Brunswick, 2017). At landfall the winds reached near hurricane strength causing damage to more than 2000 trees in Fredericton alone (Harding, 2016). Again, damage from this storm was conveyed to the public through harrowing news headlines like Arthur Storm Photos Show the True Power of Nature and Arthur Tore Up Our Trees, Turned Culverts in Raging
Rivers, and Turned Power Lines into Skipping Ropes (Arthur Storm Photos Show the True Power of Nature, 2014; Hawkins, 2014). The public was informed of destruction to the built and natural environment, but little was written about what people could do to better prepare for the next storm. Media and reporters are missing opportunities to warn citizens that such events are likely to occur in the future.

As with Hurricane Juan, Arthur initiated a research project. Louise Comeau of the Conservation Council of New Brunswick interviewed people from two communities about Arthurs's aftermath (Harding, 2016). Comeau's agenda was to understand individual capacity for response to extreme weather events resulting from ongoing climate change (Harding, 2016). She discovered people were emotional about tree loss (Harding, 2016). People in rural areas felt they were on their own, as help was promised to them but never arrived (Harding, 2016). She recommended more education about action in the face of extreme weather events. This news story made research on urban forest benefits and the threat of climate change available to the public. News stories have a unique opportunity to inform and warn the public about the challenges urban forests face.

This media analysis demonstrates the media's tendency to report extreme weather events as rare and destructive. Such stories describe trees as dangerous, meaning municipal planners view trees as hazard rather than beneficial to 
communities. The loss of urban forest benefits, including but not limited to economic benefits provided by mature trees, are often not reported. Examples from international media stories demonstrate that reporters are missing an opportunity to educate citizens about the likely increase of extreme weather events and how to reduce urban tree loss.

\section{Discussion \& Recommendations for Urban Forest Planners}

Urban forests face environmental challenges. Thoughtful planning and management is required to ensure a long and healthy future for urban forests. The Nova Scotia Department of Natural Resources report a likely increase of extreme weather events and urge forest managers to design forests resilient to wind damage (McGrath \& Ellingsen, 2009). Designing for resilience should not be limited to commercial woodlots but implemented by urban foresters as well. The following are recommendations for urban forest planning for extreme weather events and examples of existing management that consider such events.

Structural diversity can make urban forests more resilient to extreme weather events (Steenberg et al., 2013). A variety of species and functional diversity results in better structural diversity (Ordóñez \& Duinker, 2014). A structurally diverse forest has uneven-aged trees and a variety of species. A study of one hundred and nineteen windstorm events worldwide found damage within even-aged stands worse than within uneven-aged stands (Mitchell, 2013). One reason is that uneven-aged stands are often older with greater species diversity than even-aged stands (Mitchell, 2013). Uneven-aged stands are also more likely to be natural than planted (Mitchell, 2013). Avoiding even-aged plantings where trees mature and die at the same time will result in enhanced urban forest benefits (Steenberg et al., 2013).

Improving species diversity of newly planted trees can enhance the resilience of urban forests to extreme weather events. Largely coniferous forests are more susceptible to windthrow than structurally diverse forests (Steenberg \& Duinker 2010). According to Ordóñez \& Duinker, species composition leads to functional diversity, improving forest resilience (2014). A homogenous forest is more vulnerable to climate change: therefore a variety of tree species should be planted. As described earlier in the paper, news reports have an opportunity to inform the public of these, and other, tips for residential tree plantings to encourage resilience in the face of extreme wind events.

Canadian urban forest planners should modify existing management plans to include structural and species diversity. Traditionally, urban planners have prioritized a few, non-native species in plantings (Ordóñez \& Duinker, 2014). Therefore, $50-70 \%$ of the total urban tree canopy in Canadian cities is comprised of a handful of species (Ordóñez \& Duinker, 2014). The Halifax UFMP prioritizes species

The Eye of the Storm 
diversity and recognizes its importance in the creation of a healthy urban forest (HRM Urban Forest Planning Team, 2013). The Halifax UFMP promotes the goal of overcoming decisions of former planners who planted a low-species diversity of American elm, European linden, and Norway maple (HRM Urban Forest Planning Team, 2013). Halifax is on the right track towards promoting species diversity and old-growth Acadian species to be planted in Point Pleasant Park.

A goal of both the Halifax UFMP and the Point Pleasant Park Comprehensive Plan are to promote natural regeneration in Point Pleasant Park. Steenberg \& Duinker recommend encouraging regeneration of red spruce among other old-growth Acadian species (2010). To do this, red spruce seedlings are to be transplanted from overly dense plots to thin areas where tree growth is slow (Steenberg \& Duinker, 2010). Thinning areas overstocked with red spruce will promote faster individual tree growth and encourage old-growth species structure (Stenberg \& Duinker, 2010). The planting of native species could reduce exotic, non-native species from dominating the park (Steenberg \& Duinker, 2010). Regeneration of red spruce will return Point Pleasant Park to its natural aesthetic which citizens of Halifax have indicated they value.

Vancouver citizens value Stanley Park as an untouched natural environment (Kheraj, 2007). The media frames extreme weather events as anomaly when they occur, although they follow a historical weather pattern. According to Kheraj "Powerful, non-human forces have always reshaped the landscape of Stanley Park" and Vancouver residents often overlook this fact $(2007$, p. 577). These weather patterns should be well understood by urban foresters to ensure preparedness for extreme weather events and to further urban forest protection. Steps in urban forest planning should be taken by Vancouver to avoid further canopy cover loss from future severe windstorms.

The Stanley Park restoration plan opted for a human centered management strategy over adaptive management (Vancouver Park Board, 2007). Stanley Park's restoration plan focuses on how human interventions will affect the evolution of the forest (Vancouver Park Board, 2007, p. 15). A goal of Stanley Park planning is urban forest resilience. Within a socio-ecological context, resilience can be described as the ability of a system to continually change and adapt (Berkes \& Ross, 2013). Human intervention will be integral to urban forest management, but this should be paired with a strong understanding of the patterns of natural disturbances that affect Vancouver.

Improving species and structural diversity and assisting natural regeneration in two Canadian urban parks will require monitoring and further studies. Urban foresters should apply adaptive management to urban forest planning. Although trends have been studied, the 
certainty of frequency and intensity of extreme weather events is unknown. Adaptive management is a learning tool for improving resource management in the face of uncertainty (Armitage, Berkes \& Doubleday, 2007). As a coastal city, Halifax has done well to prioritize adaptive management. Adaptive management can result in sustainable forest management (Duinker \& Trevisan, 2003). Sustained monitoring and assessing of the urban forest is critical for adaptive management to succeed (Duinker \& Trevisan, 2003).

\section{Conclusion}

The paper compared how extreme windstorm events in Vancouver and Halifax damaged urban trees in public parks. These parks are sites where urban citizens enjoy ample urban forest benefits, therefore these destructive events limited the public's ability to enjoy urban forest benefits. An analysis of media coverage of these events, and others, demonstrated that the media's tendency is to paint trees as dangerous and capable of creating more damage than good. Such news stories do not consider the many benefits trees provide.

Extreme weather events are considered anomaly when they happen, but nature is rarely as stable and undisturbed as people imagine it to be (Kheraj, 2007). Rather, trees require monitoring by humans in the form of sustainable urban forest management. Urban forest planning needs to consider the increased likelihood of extreme weather events in the face of anthropogenic climate change. This consideration is especially important for coastal cities such as Vancouver and Halifax. Summer and fall of 2017 saw numerous extreme weather events to the point of a news headline almost daily. Such events will have short-term and long-term effects on the urban forests, so urban forest planners should develop UFMPs that enhance urban forest benefits for the enjoyment of future generations.

\section{References}

Armitage, D., Berkes, F., Doubleday, N. (2007). Introduction: Moving beyond co-management, in D. Armitage, Berkes, \& Doubleday (Eds.), Adaptive co-management: Collaboration, learning and multilevel governance (pp. 1-15). Vancouver: UBC Press.

Arthur storm photos show the true power of nature. (2014, July 07). Huffington Post. Retrieved October 30, 2017 from http://www.huffingtonpost.ca/2014/ 07/07/arthur-storm-photosmaritimes_n_5565502.html.

Berkes, F., \& Ross, H. (2013). Community Resilience: Toward an Integrated Approach. Society \& Natural Resources, 26(1), 5-20.

Berman, P. (2015, October 19). Hurricane Juan caused some long-term damage to Halifax trees. CBC News. Retrieved September 25, 2017 from

The Eye of the Storm 
http://www.cbc.ca/news/canada/no va-scotia/hurricane-juan-treedamage-1.3276209.

Burley, S., Robinson, S., \& Lundholm, J. (2007). Post-hurricane vegetation recovery in an urban forest. Landscape and Urban Planning 85, 111-122. doi: 10.1016/j.landurbplan.2007.10.003.

Demont, J. (2003, November 25). Hurricane devastates Halifax's trees. Macleans: The Canadian Encyclopedia. Retrieved September 25, 2017 from www.thecanadianencyclopedia.ca/e $\mathrm{n} /$ article/hurricane-devastateshalifaxs-trees/.

Destructive and deadly Juan. (2016, September 29). The Weather Network. Retrieved October 29, 2017 from https://www.theweathernetwork.co $\mathrm{m} /$ news/articles/hurricane-juan-alook-back-at-one-of-canadas-mostdamaging-storms/13458.

Duinker, P. N., \& Trevisan, L. M. (2003). Adaptive management: Progress and prospects for Canadian forests. In P. J. Burton, C. Messier, D. W. Smith, and W. L. Adamowicz (Eds.), Towards sustainable management of the Boreal forest (pp.857-892). Ottawa, Ontario: NRC Research Press.
English, E. (2017, October 24). Calls for review of Cork city's tree policy after Ophelia knocks up to 600 trees. Irish Examiner. Retrieved October 28, 2017 from http://www.irishexaminer.com/irelan d/calls-for-review-of-cork-citystree-policy-after-ophelia-knocksup-to-600-trees-461507.html.

Harding, G. (2016, July 5). Storm Arthur's affect on future storm response studied. CBC News. Retrieved October 29, 2017 from http://www.cbc.ca/news/canada/ne wbrunswick/post-tropical-stormarthur-affect-future-response1.3665811.

Hawkins, M. (2014, July 10). Arthur tore up our trees, turned culverts in raging rivers, and turned power lines into skipping ropes. Wicked Ideas. Retrieved October 30, 2017 from http://wickedideas.ca/wickedstories/arthur-tore-up-our-treesturned-culverts-into-raging-riversand-turned-power-lines-intoskipping-ropes-check-out-the-wildvideo/.

HRM Urban Forest Planning Team. (2013). Halifax Regional Municipality Urban Forest Master Plan. Halifax, NS: Halifax Regional Municipality. 
IPCC. (2014). Climate change 2014 :

Synthesis report. Contribution of Working Groups I, II and III to the Fifth Assessment Report of the Intergovernmental Panel on Climate Change [Core writing tem, R. K. Pachauri and L. A. Meyer (eds.)]. IPCC, Geneva, Switzerland, 151 pp. Retrieved October 29, 2017 from http://ipcc.ch/pdf/assessmentreport/ar5/syr/AR5_SYR_FINAL_Fron t_matters.pdf.

Kheraj, S. (2007). Restoring nature: Ecology, memory and the storm history of Vancouver's Stanley Park. The Canadian Historical Review, 88(4), 577-612. doi: 10.3138/chr.88.4.577.

Kheraj, S. (2013). Inventing Stanley Park: An environmental history.

Konijnendijk, C. (2008). The forest and the city: The cultural landscape of the urban woodlot. Denmark: Springer Books.

Maclean, R. (2017, July 02). How Calgary has prepared for the next big flood in the 4 years since 2013's disaster. CBC News. Retrieved September 25, 2017 from www.cbc.ca/news/canada/calgary/c algary-flood-mitigation-projectsfour-year-anniversary-1.4162398.
Matheson, P. (2017, October 25). After the storm, who takes care of the trees? U.S. Department of Agriculture. Retrieved October 28, 2017 from https://www.usda.gov/media/blog/2 017/10/25/after-storm-who-takescare-trees.

McGrath, T., \& Ellingsen, J. (2009). The effects of Hurricane Juan on managed stands commercially thinned in central Nova Scotia. Forest Research Report for Nova Scotia Department of Natural Resources.

Mitchell, S. J. (2013). Wind as a natural disturbance agent in forests: A synthesis. Forestry, 86, pp. 147-157. doi: doi:10.1093/forestry/cps058.

New Brunswick. (2017). Post-tropical storm Arthur-July 5, 2014. Retrieved October 29, 2017 from http://www2.gnb.ca/content/gnb/en /news/public_alerts/report_damages /2014_PTSArthur.html.

NIPpaysage \& Ekistics Planning and Design. (2008, October). Point Pleasant Park: Comprehensive Plan. Halifax, NS: Canada.

Ordóñez, C. \& Duinker, P. N. (2014). Assessing the vulnerability of urban forests to climate change. NCR Research Press 22, 311-321. doi: dx.doi.org/10.1139/er-2013-0078. 
Ordóñez, C., Duinker, P. N., Sinclair, A. J., Beckley, T., \& Diduck, J. (2016, January). Determining public values of urban forests using a sidewalk inception survey in Frederiction, Halifax, and Winnipeg, Canada. Arboriculture \& Urban Forestry 42(1) 46-57.

Patten, M. (2013, September 27). A decade later, Hurricane Juan's destructive legacy lingers in Halifax. CTV News. Retrieved October 29, 2017 from http://www.ctvnews.ca/canada/adecade-later-hurricane-juan-sdestructive-legacy-lingers-inhalifax-1.1473097.

Sin, L. (2006, December 24). B.C. residents donate trees to storm ravaged Stanley Park. CanWest News. Retrieved from ProQuest database.

Statistic Canada. (2017). Canada goes urban. Retrieved September 26 2017 from http://www.statcan.gc.ca/pub/11630-x/11-630-x2015004-eng.htm.

Steenberg, J. W. N. \& Duinker, P. N. (2010). Post-hurricane coniferous regeneration in Point Pleasant Park. Proceedings of the Nova Scotia Institute of Science, 45(1), 26-54.

Steenberg, J. W. N., Duinker, P. N., \& Charles, J. (2013). The neighbourhood approach to urban forest management: The case of Halifax, Canada. Landscape and Urban Planning, 117, 135-144. doi: dx.doi.org/10.1016/j.landurbplan.20 13.04.003.

Storm Ophelia ripped the roof off Ireland today. (2017, October 16) The Journal. Retrieved October 28, 2017 from

http://www.thejournal.ie/opheliastorm-damage-3649223-Oct2017/.

Talmazan, Y. (2016, December 15). 10 years since major windstorm hits Stanley Park. Global News. Retrieved September 25, 2017 from https://globalnews.ca/news/312390 9/watch-10-years-since-majorwindstorm-hit-stanley-park/.

Vancouver's Stanley Park shows signs of recovery a year after storm wrecked havoc. (2007, December 15). The Canadian Press. Retrieved October 24, 2017 from http://ezproxy.library.dal.ca/login?ur I=https://search.proquest.com/docvi ew/360016034? accountid $=10406$.

Vancouver Park Board. (2007, April). Stanley Park Restoration: Recommended Plan. Retrieved October 24, 2017 from http://stanleyparkecology.ca/wpcontent/uploads/downloads/2012/0 
2/VPB_stanleypark_restoration_plan.

pdf.

van Wassenaer, P. J. E., Schaeffer, L., \&

Kenney, W. A. (2000). Strategic

planning in urban forestry: A $21^{\text {st }}$

Century paradigm shift for small

town Canada. The Forestry

Chronicle 76(2) 241-245. 